\title{
Emergency obstetric care among referrals in more than 24 weeks gestation at a tertiary care teaching institution in Kerala, India
}

\author{
Heera Shenoy T. ${ }^{1}$, Sheela Shenoy T. ${ }^{2}$, Remash K. ${ }^{3 *}$, Sony Simon ${ }^{4}$
}

\begin{abstract}
${ }^{1}$ Department of Obstetrics and Gynecology, KMCT Medical College, Kozhikode, Kerala, India ${ }^{2}$ Department of Obstetrics and Gynecology, Govt. Medical College, Thiruvananthapuram, Kerala, India ${ }^{3}$ Department of Medicine, Malabar Medical College Hospital and Research Centre, Kozhikode, Kerala, India ${ }^{4}$ Department of Biostatistics, Travancore Medical College, Kollam, Kerala, India
\end{abstract}

Received: 28 May 2020

Accepted: 06 July 2020

\section{*Correspondence:}

Dr. Remash K.,

E-mail: heerarprabhu@gmail.com

Copyright: (C) the author(s), publisher and licensee Medip Academy. This is an open-access article distributed under the terms of the Creative Commons Attribution Non-Commercial License, which permits unrestricted non-commercial use, distribution, and reproduction in any medium, provided the original work is properly cited.

\section{ABSTRACT}

Background: One of the biggest barriers confronting efforts to reduce maternal mortality through increased skilled delivery is access to emergency obstetric care. This study aimed to look into the profile of emergency obstetric referrals. Referral-decision interval, reasons and morbidities of referral were analysed and their neonatal outcomes assessed.

Methods: This observational study reviewed 90 emergency obstetric referrals over 3 years from June 2013 to February 2016.

Results: In-labour referrals constituted the majority of emergency obstetric referrals. Preterm obstetric referrals needed emergency interventions in view of medical/obstetric indications and it was statistically significant. Referraldecision and referral-arrival interval was significant in emergency group (p-value-0.001). Babies born to mothers who were obstetric emergency referrals had extended NICU stay ( $p$-value-0.001). There was a maternal death and four near-misses in this research.

Conclusions: Timely decisions taken during interhospital emergency referrals resulted in better perinatal outcomes by prompt maternal interventions.

Keywords: Emergency, Foetal, Maternal, Morbidity, Obstetric, Perinatal, Referrals

\section{INTRODUCTION}

In health care delivery systems, referral is a set of activities undertaken by a health care provider or facility in response to its inability to provide the quality or type of intervention suitable to the need of the patient. To be effective, referral should be a two-way process that requires coordination and information exchange between the referring facility (usually at the primary care level) and the first referral hospital. The process of implementation of referral systems must be seen against the background in Kerala of relatively high health status indicators, uneven achievements across districts and between districts, less differences between urban and rural areas and between the rich and the poor. The presence or absence of referral systems and the degree to which they are effective are among the indicators of access to care as well as quality. Ensuring access in appropriate matter is the concern of equity health care delivery. Referrals should be made to the nearest appropriate and affordable health facility which should as far as possible be free in cases of emergency. ${ }^{1-4}$

Access to appropriate health care including skilled birth attendance at delivery and timely referrals to avail emergency obstetric services can greatly reduce maternal deaths as well as disabilities. Timely access to emergency care is therefore seen as an indicator of a successful 
health system. The inability of most women to access timely emergency obstetric care (E m OC) remains one major challenge in addressing the burden of maternal mortality worldwide. ${ }^{5-7}$

An obstetric emergency is defined as an obstetric complication or situation of serious and often dangerous nature, developing suddenly and unexpectedly and demanding immediate attention in order to save life. Referral institutes/tertiary care facilities should be equipped to receive such referrals. In the case of maternal and neonatal care this includes facilities capable of providing basic emergency obstetric care (BEOC) and comprehensive emergency obstetric care (CEOC). Health professionals should be available to provide care in hospitals once referrals are made.

India has a maternal mortality ratio (MMR) of 162 deaths per 100,000 live births and accounts for $17 \%$ of global maternal deaths. ${ }^{8}$ Kerala is a high-performing Indian state with regards to health indicators, with an MMR of 31 per 100,000 , an institutional delivery rate of $99 \%$ and almost universal antenatal care. Kerala has a $94 \%$ literacy rate and over $90 \%$ of houses having electricity and a toilet facility. ${ }^{9}$ In order for referral systems to function effectively the lower levels must be operated by appropriately skilled personnel who have the necessary infrastructure. This ensures that there is delivery of the range of services required and unnecessary referral is avoided. Self-referral to higher levels or skipping of one step overburdens secondary and tertiary care facilities where unit costs are higher, underutilizes health centres and other primary care facilities and increases out-ofpocket payments to the majority of general fee-paying patients. Referrals are expected to take place from first stratum to the second and third stratum with a corresponding decrease in the quantity of referrals going to the higher levels. The referral documents from the health centre should have minimum amount of information when patients are referred to the hospital. The lack of a referral letter or a poor quality referral letter can compromise management of a patient. ${ }^{10}$ Community awareness needs to be created regarding availability of health care facility during their antenatal care and discourage self-referrals due to "want of good care," "for normal delivery" or "perceived risk." Further, feedback from the receiving facility to the initiating facility will enable health system strengthening and improve health care delivery.

In this study, authors have analysed emergency obstetric referrals - their sources of referral, reasons necessitating urgent referral, in-labour referral, distance travelled to receive comprehensive emergency obstetric care, birth weight and gestational age at which referral was done and GA of decision, mean NICU stay and morbidities in the mother.

The main aim and objective of this study is to analyse emergency obstetric referrals-their sources of referral, reasons necessitating urgent referral, in-labour referral, distance travelled to receive comprehensive emergency obstetric care, birth weight and gestational age at which referral was done and GA of decision, mean NICU stay and morbidities in the mother.

\section{METHODS}

An observational study conducted at Travancore Medical College, Kollam, a tertiary care teaching institution which receives inter-hospital transfers from Primary health centres (PHC), Community health centres and private hospitals in and around Kollam. The sample population consisted of 124 obstetric referrals of 24 weeks and beyond during June 2013 to February 2016. All booked cases and obstetric referrals of less than 24 weeks and 6 out referrals were excluded from the study. Emergency obstetric referrals were 90 and electives were 34. Study protocol was approved by the ethics committee. Using a pre-structured designed questionnaire, socio demographic details, medical co-morbidities, indications for emergency referral- maternal and foetal were obtained. Referral slips were analysed and source of referral, referral-arrival interval, documentation patterns were sought. Patient referred while in labour were specially noted. Gestational age at referral and at decision/intervention was highlighted. Neonatal weight, NICU stay in days and morbidity looked into.

\section{Statistical analysis}

Data was analysed for descriptive statistics such as mean, standard deviation and percentages were computed using SPSS for Windows version 20. $\mathrm{p}$ value $<0.05$ was considered significant.

\section{RESULTS}

The study population comprised 124 obstetric referrals which included 90 emergency and 34 elective referrals. The socio-demographic data, maternal age, domicile, maternal education and employment during pregnancy were studied and was comparable in both the groups. Mean maternal age was 27.06 in Emergency referral group. Among $16.9 \%$ of government referrals, 15 were from district hospital and were either in labour or required emergency obstetric care or level III. Sources of referral contributed equally in both emergency and elective obstetric referrals.

Emergency obstetric referrals had to be decided for operative delivery due to multiple reasons.

Emergency group had statistically significant in -labour referrals ( $\mathrm{p}$ value-0.04).

All the obstetric referrals from public health sector reached within half an hour while one third of private sector referrals travelled more than an hour for emergency obstetric care ( $p$ value 0.001 ). 
Table 1: Referral characteristics-gestational age at referral and in-labour.

\begin{tabular}{|c|c|c|c|c|}
\hline GA at obstetric referral & Emergency & Elective & Odds ratio & p value \\
\hline $24-27.6$ & $7(7.8 \%)$ & $2(5.9 \%)$ & \multirow{4}{*}{0.867} & \multirow{4}{*}{0.848} \\
\hline $28-32.6$ & $27(30.0 \%)$ & $13(38.2 \%)$ & & \\
\hline $33-36.6$ & $44(48.9 \%)$ & $15(44.1 \%)$ & & \\
\hline $37-40$ & $12(13.3 \%)$ & $4(11.8 \%)$ & & \\
\hline Total & 90 & 34 & & \\
\hline Whether referral was in-labour & Emergency & Elective & & $\mathrm{p}$ value \\
\hline Yes & $58(64.4 \%)$ & $2(5.9 \%)$ & & \multirow{2}{*}{0.001} \\
\hline No & $32(35.6 \%)$ & $32(94.1 \%)$ & & \\
\hline Total & 90 & 34 & & \\
\hline GA at decision & Emergency & Elective & Odds ratio & $\mathrm{p}$ value/odds ratio \\
\hline $24-27.6$ & $7(7.8 \%)$ & $1(2.9 \%)$ & \multirow{4}{*}{4.550} & \multirow{4}{*}{0.007} \\
\hline $28-32.6$ & $27(30.0 \%)$ & $6(17.6 \%)$ & & \\
\hline $33-36.6$ & $44(48.9 \%)$ & $13(38.2 \%)$ & & \\
\hline $37-40$ & $12(13.3 \%)$ & $14(41.2 \%)$ & & \\
\hline Total & 90 & 34 & & \\
\hline
\end{tabular}

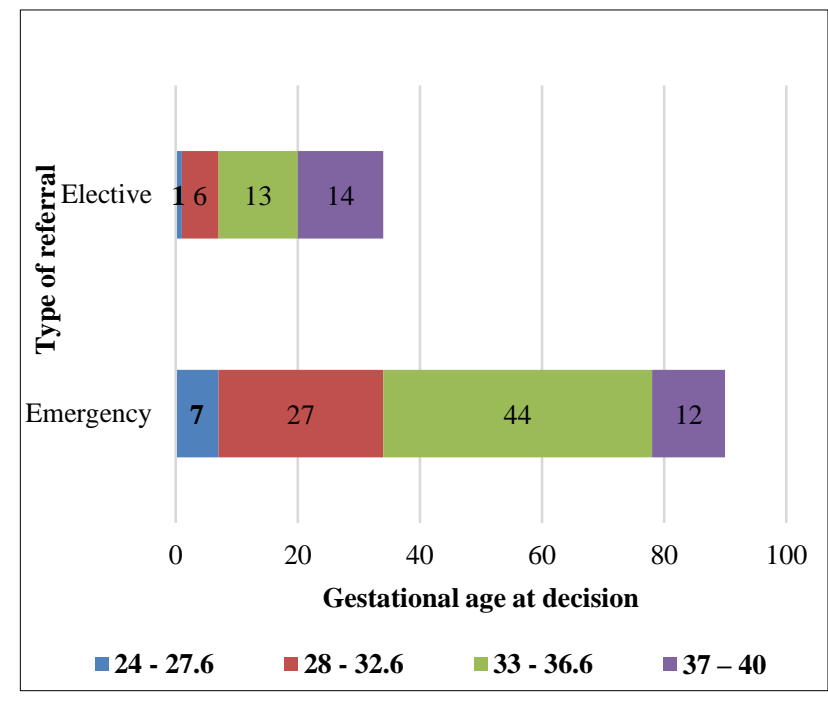

Figure 1: Decision of obstetric referrals.

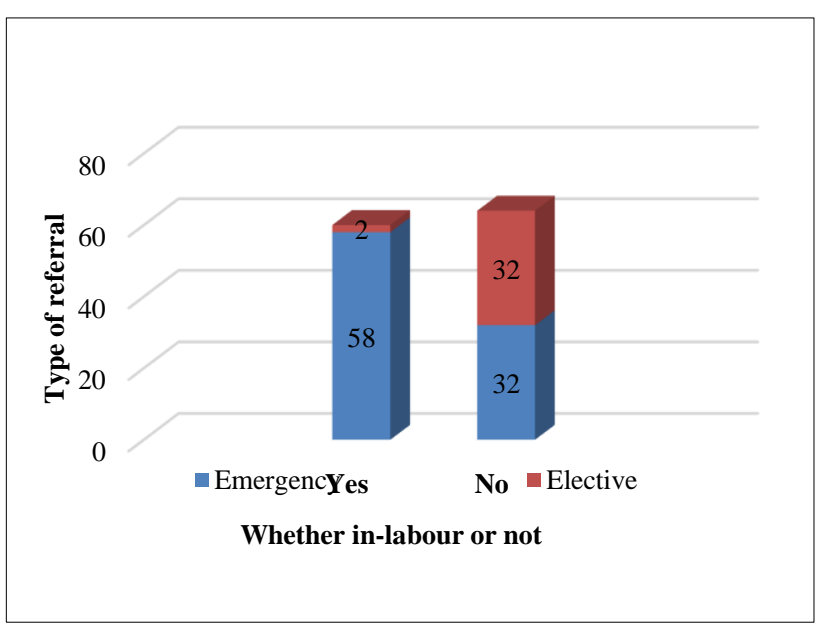

Figure 2: Labour referrals-emergency obstetric care.
Table 2: Source of referral.

\begin{tabular}{|c|c|c|c|}
\hline Referral place & Emergency & Elective & p value \\
\hline $\begin{array}{l}\text { Government } \\
\text { hospital }\end{array}$ & $15(16.7 \%)$ & $6(17.6 \%)$ & \multirow[t]{2}{*}{0.897} \\
\hline Private hospital & $75(83.3 \%)$ & $28(82.4 \%)$ & \\
\hline Total & 90 & 34 & \\
\hline $\begin{array}{l}\text { If government } \\
\text { hospital } \\
(n=21)\end{array}$ & Emergency & Elective & $\mathrm{p}$ value \\
\hline $\mathrm{CHC}$ & $0(0.0 \%)$ & $2(33.3 \%)$ & \multirow{4}{*}{0.026} \\
\hline District hospital & $13(86.7 \%)$ & $2(33.3 \%)$ & \\
\hline ESI & $0(0.0 \%)$ & $1(16.7 \%)$ & \\
\hline PHC & $2(13.3 \%)$ & $1(16.7 \%)$ & \\
\hline Total & 15 & 6 & \\
\hline \multicolumn{4}{|c|}{ Referral-arrival time } \\
\hline $\begin{array}{l}\text { Within half an } \\
\text { hour }\end{array}$ & $86(95.5)$ & $6(17.64)$ & \multirow[t]{2}{*}{0.001} \\
\hline$>$ Half an hour & $4(4.5)$ & $28(82.36)$ & \\
\hline Total & 90 & 34 & \\
\hline
\end{tabular}

Table 3: Document handed over to the in-referral centre.

\begin{tabular}{|lll|}
\hline Referral letter & $\begin{array}{l}\text { Emergency } \\
\mathbf{N = 9 0}\end{array}$ & $\begin{array}{l}\text { Elective } \\
\mathbf{N = 3 4}\end{array}$ \\
\hline Structured & 70 & 19 \\
\hline Unstructured & 18 & 14 \\
\hline $\begin{array}{l}\text { No Document } \\
\text { available }\end{array}$ & 2 & 1 \\
\hline & 90 & 34 \\
\hline $\begin{array}{l}\text { Medical, obstetric } \\
\text { details, scan }\end{array}$ & $\begin{array}{l}\text { Emergency } \\
\mathrm{N}=90\end{array}$ & $\begin{array}{l}\text { Elective } \\
\mathrm{N}=34\end{array}$ \\
\hline Available & 72 & 11 \\
\hline Not available & 18 & 23 \\
\hline
\end{tabular}


Documentation details between emergency and elective obstetric referrals.

Maternal reasons predominated public sector referrals while foetal causes dominated private referrals ( $\mathrm{p}$ value 0.05). Many patients had multiple complications at the time of referral and had to be delivered early.

Table 4: Reasons for referral-emergency.

\begin{tabular}{|c|c|c|c|}
\hline $\begin{array}{l}\text { Reasons for } \\
\text { referral }\end{array}$ & $\begin{array}{l}\text { Total } \\
\mathrm{N}=124\end{array}$ & $\begin{array}{l}\text { Emergency } \\
N=90\end{array}$ & $\begin{array}{l}\text { Elective } \\
N=34\end{array}$ \\
\hline \multicolumn{4}{|l|}{ Maternal } \\
\hline $\begin{array}{l}\text { Previous caesarean } \\
\text { in labour }\end{array}$ & 11 & 10 & 1 \\
\hline Preterm labour & 13 & 10 & 3 \\
\hline $\begin{array}{l}\text { Severe pre- } \\
\text { eclampsia }\end{array}$ & 10 & 8 & 2 \\
\hline $\begin{array}{l}\text { Multifetal } \\
\text { gestation }\end{array}$ & 13 & 11 & 2 \\
\hline $\begin{array}{l}\text { APH-abruptio } \\
\text { /praevia }\end{array}$ & 8 & 2 & 6 \\
\hline Malpresentation & 4 & 1 & 3 \\
\hline $\begin{array}{l}\mathrm{CPD} / \text { failed } \\
\text { induction }\end{array}$ & 4 & 2 & 2 \\
\hline PPROM & 14 & 12 & 2 \\
\hline \multicolumn{4}{|l|}{ Foetal } \\
\hline FGR-oligoamines & 14 & 11 & 3 \\
\hline $\begin{array}{l}\text { Doppler } \\
\text { abnormality-FGR }\end{array}$ & 10 & 10 & 0 \\
\hline $\begin{array}{l}\text { Intra-uterine } \\
\text { demise }\end{array}$ & 6 & 1 & 5 \\
\hline $\begin{array}{l}\text { Foetal distress } \\
\text { NRFHR }\end{array}$ & 9 & 7 & 2 \\
\hline Others ${ }^{\#}$ & 8 & 5 & 3 \\
\hline \multicolumn{4}{|c|}{ p-value- 0.05} \\
\hline \multicolumn{4}{|c|}{$\begin{array}{l}\text { \#Others include Rh negative, short primigravida and a case } \\
\text { of facial nerve palsy-acute episode in elective referrals, } 2 \\
\text { cases of dengue fever, } 2 \text { cases of Chicken pox, } 1 \text { case of } \\
\text { HBsAg positive in the emergency referrals. }\end{array}$} \\
\hline
\end{tabular}

There were significantly more babies born preterm in emergency obstetric referrals $(<36.6$ weeks).

Table 5: Referral outcomes-viability.

\begin{tabular}{|llll|}
\hline Foetal outcome & Frequency & Emergency & Elective \\
\hline Term & 37 & 22 & 15 \\
\hline Preterm & 98 & 77 & 21 \\
\hline IUD & 6 & 1 & 5 \\
\hline Total & 141 & 100 & 41 \\
\hline
\end{tabular}

Details of singleton and multifetal gestation. Table showing varying birth weights in obstetric referrals.

More babies were born preterm in emergency obstetric referrals $(<36.6$ weeks) resulting in more babies needing extended NICU care as they were either growth restricted or twin/triplets/being extreme prematurity ( $\mathrm{p}$ value$0.001)$.

Table 6: Referral outcome-singleton versus multifetal.

\begin{tabular}{|llll|}
\hline Variables & Number & Emergency & Elective \\
\hline $\begin{array}{l}\text { Total number } \\
\text { of babies }\end{array}$ & 141 & 105 & 36 \\
\hline Twin gestation & $9 \times 2=18$ & 16 & 2 \\
\hline Triplet gestation & $4 \times 3=12$ & 9 & 3 \\
\hline Singleton & 105 & 79 & 26 \\
\hline $\begin{array}{l}\text { Intrauterine - } \\
\text { foetal demise } \\
\text { (IUFD) }\end{array}$ & 6 & 1 & 5 \\
\hline
\end{tabular}

Table 7: Birthweights of babies of obstetric referralssurvivors versus non-survivors.

\begin{tabular}{|lllll|}
\hline & & & \\
\hline $1.000-1.499 \mathrm{~kg}$ & 31 & 3 & 25 & 3 \\
\hline $1.500-1.999 \mathrm{~kg}$ & 35 & 3 & 27 & 5 \\
\hline $2.000-2.499 \mathrm{~kg}$ & 26 & 1 & 19 & 6 \\
\hline $2.500-2.999 \mathrm{~kg}$ & 16 & 1 & 6 & 9 \\
\hline $3.000-3.499 \mathrm{~kg}$ & 14 & 1 & 7 & 6 \\
\hline$>3.500 \mathrm{~kg}$ & 2 & 0 & 1 & 1 \\
\hline Total & 141 & 21 & 89 & 31 \\
\hline
\end{tabular}

Table 8: Birthweights of babies of obstetric referralsLBW versus normal.

\begin{tabular}{|lllll|}
\hline $\begin{array}{l}\text { Variable- } \\
\text { foetal }\end{array}$ & Emergency & Elective & $\begin{array}{l}\text { Odds } \\
\text { ratio }\end{array}$ & $\begin{array}{l}\text { p- } \\
\text { value }\end{array}$ \\
\hline Weight of new-born & & & \\
\hline$<2.499 \mathrm{~kg}$ & $74(80.4 \%)$ & $18(19.6 \%)$ & 4.111 & 0.001 \\
\hline$>2.5 \mathrm{~kg}$ & $16(50.0 \%)$ & $16(50.0 \%)$ & & \\
\hline
\end{tabular}

Table 9: Neonatal ICU characteristics.

\begin{tabular}{|c|c|c|c|}
\hline NICU & Emergency & Elective & p-value \\
\hline Yes & $73(81.1 \%)$ & $16(47.1 \%)$ & \multirow{3}{*}{0.001} \\
\hline No & $17(18.9 \%)$ & $18(52.9 \%)$ & \\
\hline Total & $90(100 \%)$ & $34(100 \%)$ & \\
\hline \multicolumn{4}{|c|}{ Days in NICU $(n=96)$} \\
\hline$<2$ days & $10(13.7 \%)$ & $6(37.5 \%)$ & \multirow{4}{*}{0.033} \\
\hline 3 - 6 days & $21(28.8 \%)$ & $1(6.3 \%)$ & \\
\hline$>6$ days & $42(57.5 \%)$ & $9(56.3 \%)$ & \\
\hline Total & $73(100 \%)$ & $16(100 \%)$ & \\
\hline \multicolumn{4}{|l|}{ NICU } \\
\hline Ventilator & $51(69.9 \%)$ & $11(68.8 \%)$ & \multirow{4}{*}{0.674} \\
\hline CPAP & $13(17.8 \%)$ & $4(25.0 \%)$ & \\
\hline Phototherapy & $9(12.3 \%)$ & $1(6.3 \%)$ & \\
\hline Total & $73(100 \%)$ & $16(100 \%)$ & \\
\hline
\end{tabular}


Table 10: Maternal characteristics.

\begin{tabular}{|lllll|}
\hline $\begin{array}{l}\text { Maternal } \\
\text { stay }\end{array}$ & Total & Emergency & Elective & p-value \\
\cline { 1 - 4 }$<6$ days & \multirow{2}{*}{74} & $\begin{array}{l}54 \\
(60.7 \%)\end{array}$ & $\begin{array}{l}20 \\
(58.8 \%)\end{array}$ & \multirow{2}{*}{0.851} \\
\cline { 1 - 4 }$>7$ days & 49 & $\begin{array}{l}35 \\
(39.3 \%)\end{array}$ & $\begin{array}{l}14 \\
(41.2 \%)\end{array}$ & \\
\hline
\end{tabular}

As the elective referral babies were near term and hence had shorter NICU stay ( $<6$ days) making p-value statistically significant. Mean maternal hospital stay was similar in both the groups.

There were only 14 antenatal referrals which had to wait for elective decisions later. Remaining referrals were on time, prompt and hence averted maternal morbidity and mortality.

Table 11: Referral-decision gestational age.

\begin{tabular}{|lllllll|}
\hline $\begin{array}{l}\text { GA at referral } \\
\text { (in weeks) }\end{array}$ & \multicolumn{2}{l}{ GA at decision( in weeks) } & & & Fisher's exact \\
test value & p-value \\
\hline $24-27.6$ & $\mathbf{2 4 - 2 7 . 6}$ & $\mathbf{2 8 - 3 2 . 6}$ & $\mathbf{3 3 - 3 6 . 6}$ & $\mathbf{3 7 - 4 0}$ & 1 & 186.145 \\
\hline $28-32.6$ & 8 & - & - & 3 & 6.001 \\
\hline $33-36.6$ & - & 33 & 53 & 6 & \\
\hline $37-40$ & - & - & - & 16 & \\
\hline Total & - & - & 57 & 26 & \\
\hline
\end{tabular}

p-value calculated by fisher's exact test, $\mathrm{p}<0.05$ considered as significant

\section{DISCUSSION}

In this descriptive study there were 1600 deliveries which constituted 131 in-referrals and 7 out- referrals which in this study was $8 \%$ similar to $9.4 \%$ in Chaturvedi. ${ }^{11} 73.4 \%$ were in the age group of 20-30 years as in a similar research. ${ }^{12}$ Public sector had statistically significant inlabour referrals ( $p$ value-0.04) in contrast to inter-hospital transfers in Brunei where antenatal referrals constituted the majority. ${ }^{13}$ All the obstetric referrals from public health sector reached within half an hour while one third of private sector referrals travelled more than an hour for emergency obstetric care (p-value 0.001) similar to Brunei study but in contrast to Sheik et al. ${ }^{14}$ The high proportion of referrals and the experience faced during the same are probably a reason why pregnant women in India chose to deliver at private institutions to avoid transfers. $^{15}$

\section{Maternal}

In this study, the most common reason for referrals was obstetric indications. Pre-eclampsia, preterm labour, need for NICU care, multifetal gestation, previous caesarean and foetal causes like foetal growth restriction (FGR) with worsening doppler parameters were the most commonly reported causes. Pre-eclampsia was detected in $11 \%$ and severe anaemia in $8 \%$ of all pregnant women in the study by Alehgen. ${ }^{16}$ Pre-eclampsia and eclampsia are among the top three causes of maternal mortality in India. ${ }^{17}$ As per the World Health Organization, India tops the list of 10 nations contributing 60 percent of the World's premature deliveries. The presence of high-risk maternal and neonatal factors generates referrals of such cases to higher-level facilities for labour management. Incorporation of cost-effective strategies such as timely administration of corticosteroids and emergency neonatal care at secondary-level facilities should be considered for management of premature babies. In the present study, asthma was a significant morbidity among emergency public sector obstetric referrals ( $p$-value-0.001) as in a similar research. ${ }^{15}$ A study conducted in Tanzania reported that among $28 \%$ of referred patients, $70 \%$ were referred due to demographic risks, $12 \%$ due to obstetric historical risks, $12 \%$ prenatal and $5.5 \%$ intrapartum and postpartum risks. ${ }^{18}$ Jahn and De Brouwere identified a core set of indications for referral which would produce referral rates of $6 \%$ to $10 \%$ and reduce a lot of unnecessary high-risk referrals mainly previous caesarean section (obstetric historical risk), breech presentation, transverse lie, multiple gestation, hypertension, and severe anaemia. ${ }^{19}$ Emergency maternal referrals included previous caesarean in labour, preterm labour, severe preeclampsia, multi-foetal gestation. $27.6 \%$ referrals were for hypertensive disorders and 34.5\% were for preterm labour in the study by Agarwal et al. ${ }^{20}$ There were 2 chronic HBV infections similar to Agarwal et al. Infections included 4 dengue fever cases, 2 cases of Chickenpox in labour in emergency referrals. Immediate intervention was needed for severe pre-eclampsia, eclampsia, previous caesarean in labour, antepartum haemorrhage preterm labour and higher order pregnancies remote from term. Agarwal et al, reported 16 patients with eclampsia, a major preventable cause of maternal mortality. Most of the patients 56\% (42\% in private hospitals and $14 \%$ in public) referred for better neonatal care either due to anticipated preterm birth, foetal growth restriction, oligohydramnios, foetaldistress, doppler abnormality had to be managed with 
emergency caesarean delivery. Emergency in-referrals in Rajasthan had reasons such as obstructed labour (25\%), antepartum haemorrhage (16\%), pregnancy induced hypertension $(16 \%)$, severe anaemia $(14 \%)$, complicated abortion (12\%), post-partum haemorrhage $(6 \%)$ and twin pregnancy $(6 \%){ }^{21}$

Authors had seven out-referrals (5.6\%), two cases of complete placenta previa from public sector and five cases from private sector. (Scrub typhus, swine flu, autoimmune thrombocytopenia, hepatitis A, PPROM) Chaturvedi reported that $5.9 \%$ women seeking delivery care were referred out. ${ }^{11}$ The out-referral rate was highest from PHCs (14\%) followed by $\mathrm{CHCs}(8 \%)$ and tertiary hospitals $(1 \%)$. Half of the referrals from PHC were directly to tertiary hospitals, bypassing the CHCs. There were $11 \%$ "near-miss" cases in Kaul et al and 4 nearmiss" $(3.22 \%)$ referrals from our private sector needing multidisciplinary care. ${ }^{22}$

Kirti et al in a similar study had $34 \%$ referrals from state general hospitals and $27 \%$ rural hospitals while $9 \%$ were only from private hospitals. ${ }^{23}$ Cases were similar in distribution from both private and public sector in both emergency and elective groups. There were significantly more babies born preterm in emergency obstetric referrals ( $<36.6$ weeks) resulting in more babies needing extended NICU care as they were growth restricted/twin or triplets/being extreme premature ( $\mathrm{p}$ value-0.001).

\section{Morbidity}

There were 4 near misses which were due to severe preeclampsia and HELLP syndrome. Ten cases needed blood transfusion. 12 cases were given Mag-sulphate regime for impending eclampsia/eclampsia/severe preeclampsia. There were 2 cases of posterior reversible encephalopathy syndrome. All the 7 mothers who needed ventilator support not related to anesthesia were emergency obstetric referrals. A maternal death in a G5 P2 L2 A2, previous caesarean, pre-GDM and hypertensive presented with rupture uterus in shock reached in half an hour. Caesarean hysterectomy was done and five units of Packed RBCs were transfused and maternal death could not be averted. Mean maternal hospital stay was similar in both the groups.

\section{Foetal}

Out of 141 babies, there were 120 survivors. NICU admissions were statistically significant in emergency referrals ( $p$-value 0.001 ) due to preterm referrals and very low-birth weight babies. As the elective referral babies were near term and had shorter NICU stay ( $<6$ days), pvalue was statistically significant. Mean hospital stay in private sector was 10.17 days while it was only 7.62 days in government referrals. Survival rate of babies in this study was $84.5 \%$ due to the state-of-the-art neonatal care facilities. $77.3 \%$ were low birth weight babies of less than $2500 \mathrm{~g}$ in contrast to $56 \% \mathrm{LBW}$ babies in Rathi et al. ${ }^{24}$
A total 21 neonates succumbed to prematurity, respiratory distress, hypoxic ischemic encephalopathy and sepsis. The perinatal mortality rate is 14.63 . There were 11 neonatal deaths in babies of multifetal gestation. In a similar study 25 , total number of live births were 73 $(78.5 \%)$ among which $28(30 \%)$ required neonatal admission and $5(5.3 \%)$ had early neonatal death.

\section{Strengths}

This study provides valid information on the different variables of referral in obstetric emergencies to a tertiary health facility in the state of Kerala, where there is little research conducted on the referral process and other possible challenges encountered in receiving antenatal care at these facilities.

The limitation of this study was, this study only focused on the receiver end of the referral system and to have a comprehensive view of the challenges of the entire system it will be prudent to involve research on the sending facilities.

\section{CONCLUSION}

Maternal mortality can be averted by having maternal near -misses in developing countries by effective referral systems. Specific guidelines for "whom to refer", "how to refer" "when to refer" and "where to refer" would be helpful in making timely referral. Initiatives to improve timely transportation system for obstetric emergencies are vital in ensuring patients' safety and continuity of care during transfer. Communication between referring and receiving facilities should be enhanced and feedback should be entertained. Ensuring an effective referral system will thus need a strong collaboration and coordination among the various levels of care. Strengthening the referral systems can play a critical role in timely management of high-risk obstetric cases and eventually improve maternal and neonatal outcome.

\section{ACKNOWLEDGMENTS}

Authors would like to thank Dr K. T. Shenoy, Retired Professor and Clinical Epidemiologist Medical College Trivandrum and Mr Sony Simon, bio-statistician of Travancore Medical College and all the participants for their help and assistance.

Funding: No funding sources

Conflict of interest: None declared

Ethical approval: The study was approved by the Institutional Ethics Committee

\section{REFERENCES}

1. Park K. Textbook of Preventive and Social Medicine $17^{\text {th }}$ ed. Jabalpur. Banarasidas Bhanoj Publishers; 2000: 632. 
2. Thaddeus S, Maine D. Too far to walk: maternal mortality in context. Soc Sci Med. 1994;38:1091-1110.

3. Brun JL, Billeaud C, Elleau C, Guyon F, Roux D, Dallay D, et al. Maternal transport to the Bordeaux University Hospital: a retrospective study of 263 cases (1996-1998). J Gynecol Obstet Biol Reprod. 2000;29(4):414-22.

4. Swain S, Prakash A. Utilisation of referral services by high risk pregnant population in rural Varanasi. Indian J Matern Child Health. 1992;3(3):74-6.

5. Koblinsky M, Chowdhury ME, Moran AC, Ronsmans C. Maternal morbidity and disability and their consequences: neglected agenda in maternal health. J Health Popul Nutr. 2012;30:124-30.

6. Lee AC, Lawn JE, Cousens S, Kumar V, Osrin D, Bhutta ZA, et al. Linking families and facilities for care at birth: what works to avert intrapartum related deaths? Int J Gynecol Obstet. 2009;107(1):65-8.

7. World Health Organisation, UNICEF, UNFPA, World Bank, UN Population Division. Trends in maternal mortality: 1990 to 2013. Estimates by WHO, UNICEF, UNFPA, the World Bank and the United Nations Population Division. Geneva: World Health Organisation; 2014.

8. Shailja S, Singh M. National health policy 2017: Can it lead to achievement of sustainable development goals? Available

https://www.researchgate.net/profile/Mitasha_Singh/pu blication/322287585_National_health_policy_2017_Ca n_it_lead_to_achievement_of_sustainable_development _goals/links/5a505 0140f7e9bbc10538ef7/Nationalhealth-policy-2017Can-it-lead-to-achievement-ofsustainabledevelopment-goals.pdf. Accessed on 27 November 2018.

9. Chandramouli C. Census of India 2011: Provisional population totals: Paper 1 of 2011. India: Series 1. New Delhi: Office of the Registrar General and Census Commissioner, India; 2011.

10. Akbari A, Mayhew A, Al-Alawi MA, Grimshaw J, Winkens R, Glidewell E, et al., authors. Interventions to improve outpatient referrals from primary care to secondary care. Cochrane Database Syst Rev. 2008;4:CD005471.

11. Chaturvedi S, Randive B, Diwan V, De Costa A. Quality of obstetric referral services in india's jsy cash transfer programme for institutional births: a study from Madhya Pradesh Province. PLoS ONE. 2014;9(5):e96773.

12. Morsheda B, Shamsun N, Hashima EN. Assessing the MANOSHI referral system addressing delays in seeking emergency obstetric care in Dhaka's Slums. MANOSHI working paper series Manoshi-WP10:1-36 published by ICDDR, B, BRAC. 2010;10.

13. Ohn HT, Patrick DC, Zaw W, Mary K, Hnin YK, Herni B. Inter-hospital emergency obstetric referrals to the labour ward of RIPAS Hospital Brunei Int Med J. 2011;7(1):22-33.

14. Sheikh A, Dunphy J, Humphries C, MacArthur C, Manaseki-Holland S. Maternity handover in Kerala: a cross sectional study. Int $\mathbf{J}$ Community Med Public Health. 2018;5:3760-6.

15. Sodani PR, Sharma K. Training needs Assessment of Public Health Programmes in Maternal and Neonatal Care. Indian J Maternal Child Health. 2011;13(4):1-8.

16. Alehagen SA, Finnstrom $\mathrm{O}$, Hermansson GV, Somasundaram KV, Bangal VB, Patil A, et al Nursebased antenatal and child health care in rural India, implementation and effects: an Indian-Swedish collaboration. Rural Remote Health. 2012;12(3):2140.

17. Patel HC, Singh BB, Moitra M, Kantharia SL. Obstetric referrals: scenario at a primary health centre in Gujarat. Natl J Community Med. 2012;3:711-4.

18. Pembe AB, Carlstedt A, Urassa D, Lindmark G, Nyström L, Darj E. Effectiveness of maternal referral system in a rural setting: a case study from Rufiji district, Tanzania. BMC Health Serv Res. 2010;10:326.

19. Jahn A, De Brouwere V. Referral in pregnancy and childbirth: Concepts and strategies. In: Press I, editor. De Brouwere V, Van Lerberghe W. Safe motherhood strategies: a review of the evidence. Antwerp; 2001.

20. Agarwal N, Singla R, Dhaliwal L, Suri V. Audit of emergency obstetric referrals - a pilot study from tertiary care centre of North India Bangladesh J Obstet Gynaecol. 2015;30:25-2.

21. Hitesh J. Perceptions and constraints of pregnancy related referrals in rural Rajasthan. J Family Welfare. 1996;42(1):24-9.

22. Kaul V, Bagga R, Jain V, Gopalan S. The impact of primary postpartum hemorrhage in "near-miss" morbidity and mortality in a tertiary care hospital in North India. Indian J Med Sci. 2006;60(6):233-40.

23. Narsaria K, Mukhopadhaya P, Kyal A, Agarwal K, Agarwal A, Sanghi S. Study of obstetric referrals -one year experience at a tertiary care centre in West Bengal HECS. Int J Com Health Med Res. 2017;3(3):32-6.

24. Rathi C, Gajria K, Soni N. Review of referred obstetric cases-Maternal and perinatal outcome. Bombay Hospital J. 2010:52:52-6.

25. Devineni K, Sodumu N. A study of spectrum of referral pattern at a tertiary teaching hospital towards better obstetric care. IAIM. 2016;3(8):193-8.

Cite this article as: Shenoy HT, Shenoy ST, Remash K, Simon S. Emergency obstetric care among referrals in more than 24 weeks gestation at a tertiary care teaching institution in Kerala, India. Int J Reprod Contracept Obstet Gynecol 2020;9:3313-9. 